\title{
Thermostable and Alkalistable Xylanases Produced by the Thermophilic Bacterium Anoxybacillus flavithermus TWXYL3
}

\author{
Joshua T. Ellis and Timothy S. Magnuson \\ Department of Biological Sciences, Idaho State University, P.O. Box 8007, Pocatello, ID 83209, USA \\ Correspondence should be addressed to Timothy S. Magnuson, magntimo@isu.edu
}

Received 26 June 2012; Accepted 19 July 2012

Academic Editors: B. Ayo and J. Ruiz-Herrera

Copyright (C) 2012 J. T. Ellis and T. S. Magnuson. This is an open access article distributed under the Creative Commons Attribution License, which permits unrestricted use, distribution, and reproduction in any medium, provided the original work is properly cited.

\begin{abstract}
With the rising cost and finite supply of fossil energy, there is an increasing economic incentive for the development of clean, efficient, and renewable domestic energy. The activities of microorganisms offer the potential conversion of lignocellulosic materials into fermentable sugars, usable for downstream fermentation processes. Strain TWXYL3, a thermophilic facultative anaerobe, was discovered in the Alvord Basin hydrothermal system in Oregon, USA. Phylogenetic analysis of strain TWXYL3 showed it to be $99 \%$ similar to the 16S rRNA gene of Anoxybacillus flavithermus WL (FJ950739). A. flavithermus TWXYL3 was shown to secrete a large multisubunit thermostable xylanase complex into the growth medium. Xylanase induction was achieved by resuspending the isolate in a selective xylan-containing medium. Extracellular xylanase activity showed a temperature optimum of $65^{\circ} \mathrm{C}$ and retained thermostability up to $85^{\circ} \mathrm{C}$. Extracellular xylanase activity showed a bimodal pH optimum, with maxima at $\mathrm{pH} 6$ and $\mathrm{pH}$ 8. Electrophoretic analysis of the extracellular xylanase shows 5 distinct proteins with xylanase activity. Strain TWXYL3 is the first xylanolytic isolate obtained from the Alvord Basin hydrothermal system and represents a new model system for development of processes where lignocellulosics are converted to biofuel precursors.
\end{abstract}

\section{Introduction}

Xylanases are enzymes that catalyze the hydrolysis of 1,4$\beta$-D xylosidic linkages in xylan, the second most abundant polysaccharide in nature after cellulose, and the most abundant hemicellulose in plant cell walls $[1,2]$. There has been a resurgence in interest in microbial xylanases due to their numerous uses in industrial applications, such as biobleaching of pulp [3-5] and most notably the conversion of lignocellulosic materials into fermentable substrates for production of economical and environmentally attractive biofuels $[6,7]$. The complete hydrolysis of xylan involves several main-chain cleaving enzymes: endoxylanase (endo- $\beta$ 1,4-xylanase), $\beta$-xylosidase (xylan 1,4- $\beta$-xylosidase), and $\alpha$ glucuronidase ( $\alpha$-glucosiduronase) and side-chain cleaving enzymes: $\alpha$-arabinofuranosidase ( $\alpha$-L-arabinofuranosidase) and acetylxylan esterase $[8,9]$. Endo $\beta-1,4$ xylanase is one of the most common enzymes in xylan hydrolysis. This enzyme hydrolyzes the bonds between xylose subunits in the polymer of xylan to produce oligosaccharides, which in turn can be converted to xylose by $\beta$-xylosidase $[4,10]$.

The microbial degradation of lignocellulose is an important process because of the reliance all earth biota have on recycling of carbon and supply of both inorganic and organic carbon forms for life. The metabolic ability to recycle this carbon can be applied to creating liquid fuels, in that the sugars produced from lignocellulolysis can be converted to fuels such as ethanol and butanol. Lignocellulolytic microorganisms are ubiquitous in nature and can be isolated from plant residues such as agricultural waste products [11], or from hot spring environments where organic carbon is available $[12,13]$. Members of the bacterial genera Anoxybacillus and Bacillus have been shown to secrete a variety of lignocellulolytic enzymes such as cellulases [1416] and xylanases $[6,15-23]$. These organisms produce extracellular enzymes to depolymerize hemicellulose, lignin, and cellulose present in the biosphere for a source of carbon and energy, and their xylanases are of great interest for industrial applications $[6,21]$. Xylanases can be used for 
converting lignocellulosic agricultural waste products, which are very abundant, into fermentable sugars to generate carbon neutral liquid fuels [24, 25], as well as decreasing the amount the biologically detrimental chlorine necessary for biobleaching processes [3-5].

A wide variety of lignocellulolytic enzymes are commercially available; however, these enzymes are still very costly [26], due to low expression levels and the overall cost of growing the organisms to express these enzymes, consequentially limiting the efficiency of industrial-scale saccharification processes. The conversion of lignocellulosic feedstocks has been recognized as a major bottleneck in the process of biofuel production [27], due to the recalcitrant nature of plant cell walls, enzyme efficiency, and biomass quality [28]. This drives the continued discovery of novel enzymes in order to establish a better database of enzymes and identification of more efficient enzymes [29]. Additionally, the discovery of thermostable and alkalistable enzymes is desirable in order to increase catalytic efficiency throughout industrial processes due to variable conditions and treatment temperatures [6]. This study was performed to gain a better understanding of Anoxybacillus flavithermus TWXYL3, which was isolated from the Alvord Basin hydrothermal system in Oregon, and its extracellular xylanase enzymes.

\section{Materials and Methods}

2.1. Isolation and Cultivation. A. flavithermus TWXYL3 was isolated on Hot Springs Medium (HSM) pH 7, containing (in $\mathrm{mg} \mathrm{L}^{-1}$ ) oat spelts xylan (7500), $\mathrm{H}_{3} \mathrm{BO}_{3}$ (80.1), $\mathrm{NaCl}$ (341.0), $\mathrm{NaNO}_{3}(4.0), \mathrm{KCl}(54.7), \mathrm{K}_{2} \mathrm{HPO}_{4}(100.0)$, $\mathrm{MgCl}_{2} \cdot 7 \mathrm{H}_{2} \mathrm{O}$ (3.0), Wolfe's vitamin solution $\left(10 \mathrm{mLL}^{-1}\right)$, and $100 \mathrm{X}$ Micronutrient solution $\left(10 \mathrm{~mL} \mathrm{~L}^{-1}\right)$, with addition of $0.5 \%$ Yeast Extract, $100 \mathrm{X} \mathrm{NaHCO}_{3}$, and $100 \mathrm{X} \mathrm{CaCl} 2$ prior to inoculation. Xylan was pretreated with $0.1 \mathrm{M} \mathrm{NaOH}$ and heated to solubilize the material prior to addition. For solid agar plates, the medium was supplemented with $15 \mathrm{~g} \mathrm{~L}^{-1}$ agar. Plant material on the periphery of Tinky-Winky Pool $\left(65^{\circ} \mathrm{C}\right)$ was suspended in $10 \mathrm{~mL}$ of HSM containing $7.5 \mathrm{~g} \mathrm{~L}^{-1}$ oat spelt xylan and incubated at $65^{\circ} \mathrm{C}$ for 1 week. Aliquots of enrichment culture were plated onto HSM agar with oat spelt xylan. Colonies showing distinct clearing zones were transferred to fresh agar plates three times to ensure purification of the isolate. Colonies showing clearing were transferred three times to fresh agar plates.

\subsection{S rRNA Sequence Determination and Phylogenetic} Analyses. Total genomic DNA was isolated from mid-log phase cultures using the DNeasy Tissue Extraction Kit (Qiagen Inc., Valencia, CA) according to the manufacturer's instructions. PCR-mediated amplification of the 16S rRNA gene was performed using primers 8F and 1492R [30] along with Platinum Taq polymerase (Invitrogen Corp., Carlsbad, CA). Sequencing of the PCR products was performed using 8F, 338F, 338R, 907F, 907R, and 1492R [30]. All DNA sequences were determined by the Idaho State University (ISU) Molecular Research Core Facility.

The $16 \mathrm{~S}$ sequences obtained were aligned using sequences obtained from the nonredundant NCBI database (http://www.ncbi.nlm.nih.gov) and the CLUSTALW program found in the BioEdit program (version 7.0.5.3, Department of Microbiology, North Carolina State University, Raleigh, NC). Sequences from the full-length 16S rRNA genes from multiple closely related characterized organisms resulting from BLAST, along with multiple distantly related organisms, were BLAST-searched and used in the alignment to establish relationships among TWXYL3 and phylogenetically related isolates. Eighteen sequences were used in the alignment and employed in maximum-likelihood analysis utilizing the PAUPBOOT package (Luobin Yang, Idaho State University) with 100 bootstraps. Escherichia coli strain KCTC 2441 (EU014689.1) was used to root the tree.

2.3. Enzyme Assays. Xylanase activity was measured by using Remazol Brilliant Blue dyed xylan (RBB-xylan, Sigma Chemical Co. Ltd., St. Louis, MO), which is RBB covalently coupled to 4-O-methyl-D-glucurono-D-xylan. RBB dyed xylan is a soluble chromogenic substrate that measures the breakdown of the xylan polymer by means of dye release from the substrate [31]. The substrate was dissolved in optimal reaction buffer to $10 \mathrm{mg} / \mathrm{mL}$ in $50 \mathrm{mM}$ MES pH 6 for strain TWYL3 and reacted with enzyme at optimal catalytic temperature for 1 hour. The reaction was terminated with 3 volumes of $95 \%$ ethanol. After standing for approximately 5 minutes at room temperature, the precipitated substrate was removed by centrifugation at $2500 \mathrm{~g}$ for 5 minutes and absorbance was measured at $595 \mathrm{~nm}$ [17] using a Shimadzu UV-2401 PC spectrophotometer (Shimadzu Corp., Columbia, MD). One unit is defined as the amount of enzyme that catalyses the release of 1 absorbance unit of free RBB-xylan produced/minute/mg protein. These standard conditions were used for all studies. Xylanase from Trichoderma viride was utilized throughout as the positive control. Buffer was used in place of enzyme to serve as the negative control for all enzyme experiments.

\subsection{Protein Determination. Protein concentration was deter-} mined using the bicinchoninic acid-copper reduction method as described by Smith et al. [22]. Briefly, $1 \mathrm{~mL}$ of working reagent (bicinchoninic acid/copper sulfate mixed at a $50: 1$ ratio) was added to $100 \mu \mathrm{L}$ of sample, and the absorbance was measured at $562 \mathrm{~nm}$ after incubating at $37^{\circ} \mathrm{C}$ for 30 minutes. Different concentrations of bovine serum albumin (BSA) were used as a protein standard: 0, 0.4, 0.8, $1.2,1.6$, and $2.0 \mathrm{mg} / \mathrm{mL}$. One $\mathrm{mL}$ of reagent was added to $100 \mu \mathrm{L}$ BSA standardand incubated at $37^{\circ} \mathrm{C}$ for 30 minutes, and the absorbance was measured at $562 \mathrm{~nm}$ to establish a standard curve.

2.5. Optimization of Xylanase Production. Xylanase production was established by growing isolates in HSM with $1 \%$ oat spelt xylan. Xylan was pretreated with $100 \mathrm{mM} \mathrm{NaOH}$ and heated to solubilize the substrate. The $\mathrm{pH}$ of this solution was neutralized prior to use. Cultures were grown at optimal temperature, $65^{\circ} \mathrm{C}$ for strain TWXYL3, and samples were assayed for xylanase activity every 24 hours to determine the optimal time for xylanase production. Contents were centrifuged at $7,500 \times \mathrm{g}$ for $30 \mathrm{~min}$ at $4^{\circ} \mathrm{C}$, and the clear 


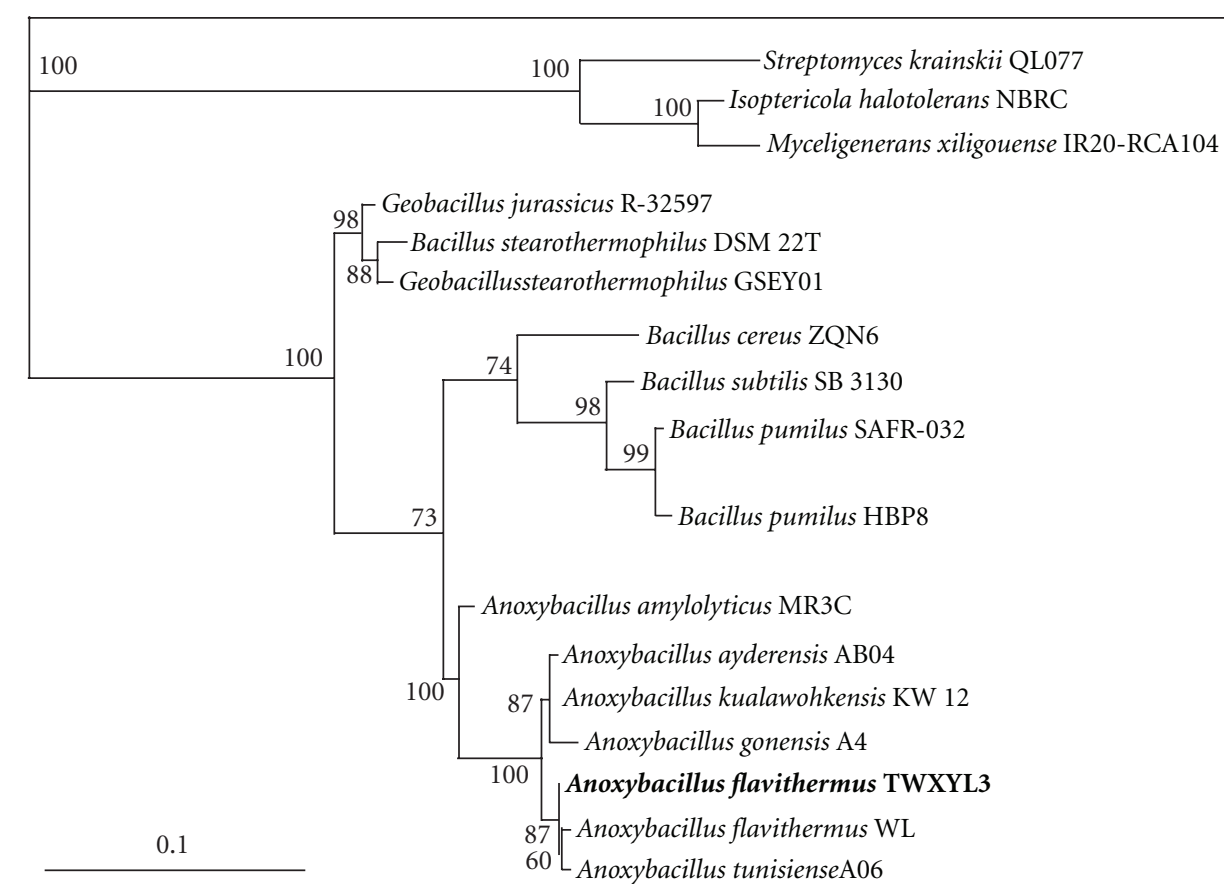

Escherichia coli KCTC 2441

FIGURE 1: Phylogenetic tree illustrating position of strain TWXYL3, based on maximum likelihood analysis using PAUPBOOT package in EGG software with 100 bootstraps. Scale bar corresponds to 0.1 substitutions per nucleotide position.

cell-free supernatant was filtered through a $0.22 \mu \mathrm{m}$ filter, concentrated 100-fold using a 10,000 molecular weight cut off (MWCO) membrane by means of a Millipore Amicon pressure cell (Millipore Corporation., Billerica, MA), and used as the enzyme source [6]. Enzyme preparations were assayed under standard conditions.

2.6. Temperature Optima and Thermostability. To determine the optimum temperature of reaction, crude enzyme preparations were assayed under standard conditions; however, the incubation temperature for the assay was varied as follows: $25^{\circ} \mathrm{C}, 37^{\circ} \mathrm{C}, 55^{\circ} \mathrm{C}, 65^{\circ} \mathrm{C}, 75^{\circ} \mathrm{C}$, and $80^{\circ} \mathrm{C}$. The influence of temperature on the catalytic activity of crude xylanases was determined by incubating enzyme preparations at temperatures ranging from $65^{\circ} \mathrm{C}$ to $95^{\circ} \mathrm{C}$ for times and ranging from 0 to 105 minutes without the presence of substrate. Enzyme preparations were then assayed under standard conditions.

2.7. $p H$ Optima. The effect of $\mathrm{pH}$ on the catalytic activity of crude xylanases was determined by assaying enzyme preparations at varying $\mathrm{pH}$ values ranging from 3 to 9 and assayed under standard conditions. $50 \mathrm{mM}$ citric acid buffer was used for $\mathrm{pH} 3-5,50 \mathrm{mM}$ Na-acetate was used for $\mathrm{pH}$ 5-5.5, $50 \mathrm{mM}$ MES was used for $\mathrm{pH}$ 5.5-6.5, $50 \mathrm{mM}$ sodium phosphate was used for $\mathrm{pH} 6.5-7.5$, and $50 \mathrm{mM}$ Tris- $\mathrm{HCl}$ was used for $\mathrm{pH}$ 7.5-9. Crude preparations were adjusted to the appropriate $\mathrm{pH}$ by means of buffer exchange. Additionally, the $\mathrm{pH}$ of the buffers were adjusted under the standard catalytic temperature to ensure accurate $\mathrm{pH}$ values throughout. Enzyme preparations were then assayed under standard conditions.
2.8. Xylanase Purification. Crude preparations were initially concentrated 100-fold using a Millipore Amicon pressure cell (Millipore Corp., Billerica, MA) with a 10,000 MWCO membrane. Partial purification of xylanase enzymes from strain TWXYL3 was achieved by use of a HiPrep 26/60 Sephacryl S-200 high-resolution size exclusion column (Amersham Biosciences Corp., Piscataway, NJ). The column was equilibrated with $50 \mathrm{mM}$ sodium phosphate buffer, $\mathrm{pH}$ 7.2, containing $150 \mathrm{mM} \mathrm{NaCl}$. Active xylanase fractions were then loaded onto a HiPrep desalting column (Amersham Biosciences Corp., Piscataway, NJ) equilibrated with $50 \mathrm{mM}$ Tris- $\mathrm{HCl}, \mathrm{pH}$ 8.45. This preparation was then loaded onto a HiPrep 16/10 Q FF ion exchange column (Amersham Biosciences Corp., Piscataway, NJ) equilibrated with $50 \mathrm{mM}$ Tris- $\mathrm{HCl}, \mathrm{pH}$ 8.45. Bound proteins were eluted with a linear gradient of $0.0-1.0 \mathrm{M} \mathrm{NaCl}$ in $50 \mathrm{mM}$ Tris- $\mathrm{HCl}, \mathrm{pH} 8.45$. The xylanase activity eluted at $0.2 \mathrm{M} \mathrm{NaCl}$.

2.9. Electrophoresis and Zymography. A 5.0\% Tricine nondenaturing (ND) polyacrylamide gel electrophoresis (PAGE) system was utilized in order to obtain enzyme profiles for extracellular fractions in their native, multimeric state [32]. Approximately $50 \mu \mathrm{g}$ of protein was loaded and electrophoresed at $30 \mathrm{~mA} /$ gel constant current at $4^{\circ} \mathrm{C}$. Gels were stained for xylanase activity (described below) and/or stained overnight in Coomassie Brilliant Blue (CBB) and destained in deionized water. Gel images were then captured and digitized using VersaDoc 3000 imaging system (Bio-Rad Laboratories, Inc., Hercules, CA). A 7.5\% Tricine sodium dodecyl sulfate (SDS) PAGE system was utilized in order to obtain enzyme profiles in their monomeric state [32]. 


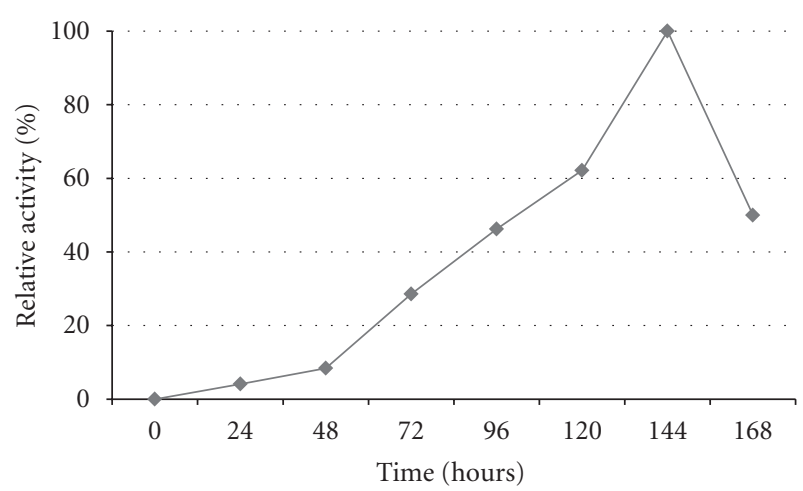

FIgUre 2: Relative total xylanase activity from strain TWXYL3 grown in HSM with $1.0 \%$ oat spelt xylan. The specific activity of the xylanase enzymes from the crude supernatant was measured at $0.08 \mathrm{U} / \mathrm{mg}$ protein at day 6 (144 hours). The values are means of three replicates at each temperature.

Approximately $50 \mu \mathrm{g}$ of protein was denatured, loaded, and electrophoresed at $30 \mathrm{~mA} / \mathrm{gel}$ constant current. Gels were dyed overnight in $\mathrm{CBB}$ and destained in deionized water. Gel images were then captured and digitized as described above.

Zymogram analysis was performed after SDS-PAGE or ND-PAGE as described by Matsui et al. [34] with some minor modifications. Briefly, samples were treated as described above and loaded onto a 7.5\% Tricine SDS-PAGE or 5.0\% Tricine ND-PAGE [32] containing 0.15\% xylan. ND-PAGE zymograms were run in a cold room set at $4^{\circ} \mathrm{C}$. After electrophoresis, the proteins were renatured (if applicable) in $100 \mathrm{mM}$ sodium phosphate buffer ( $\mathrm{pH}$ 6.8) containing $2 \%$ Triton X-100 for 30 minutes with mild shaking. Gels were then incubated in $100 \mathrm{mM}$ sodium phosphate ( $\mathrm{pH}$ 6.8) buffer for 1 hour at optimal enzyme temperature with gentle shaking. Gels were stained using $0.1 \%$ Congo red for 10 minutes, destaining with $1 \% \mathrm{NaCl}$ until zones of clearing became present, and fixed with 5\% acetic acid. Zones of clearing correspond to enzyme activities on xylan. The gel images were then captured and digitized as described above.

\section{Results}

3.1. Isolation and Phylogenetic Characterization of Strain TWXYL3. Strain TWXYL3 was obtained from submerged plant material on the periphery of a stagnant $55^{\circ} \mathrm{C}$ pool in the Mickey Hot Springs area of the Alvord Basin. Isolation was achieved by enrichment on xylan-containing synthetic hot spring medium, followed by successive streak isolation to obtain a pure culture. TWXYL3 was judged pure by $16 \mathrm{~S}$ rRNA gene sequence analysis, and consistent colony and cellular morphology. Analyses of pure culture isolate DNA did not show multiple 16S rRNA gene sequences, indicating that the culture was pure. The partial $16 \mathrm{~S}$ rRNA sequence was obtained with a length of $1,382 \mathrm{bps}$. Analysis of the $16 \mathrm{~S}$ rRNA gene showed that strain TWXYL3 had high similarity to the genus Anoxybacillus. Phylogenetic analysis of $16 \mathrm{~S}$ rRNA from strain TWXYL3, along with additional similar and dissimilar

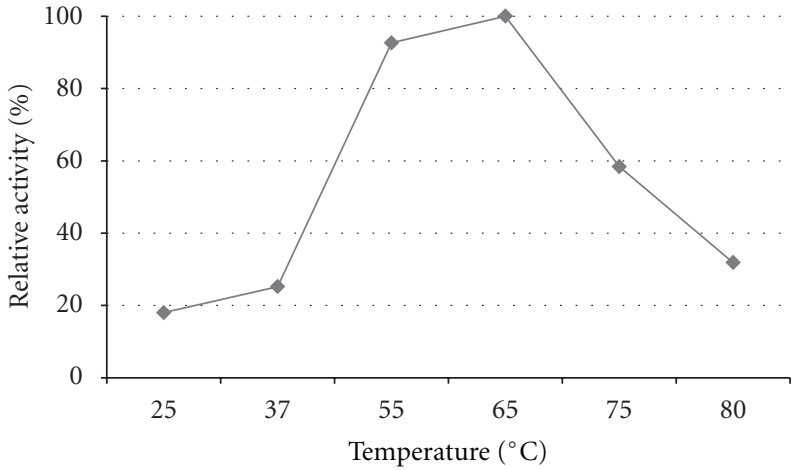

FIGURE 3: Optimal temperature of xylanases from strain TWXYL3. The values are means of three replicates at each temperature.

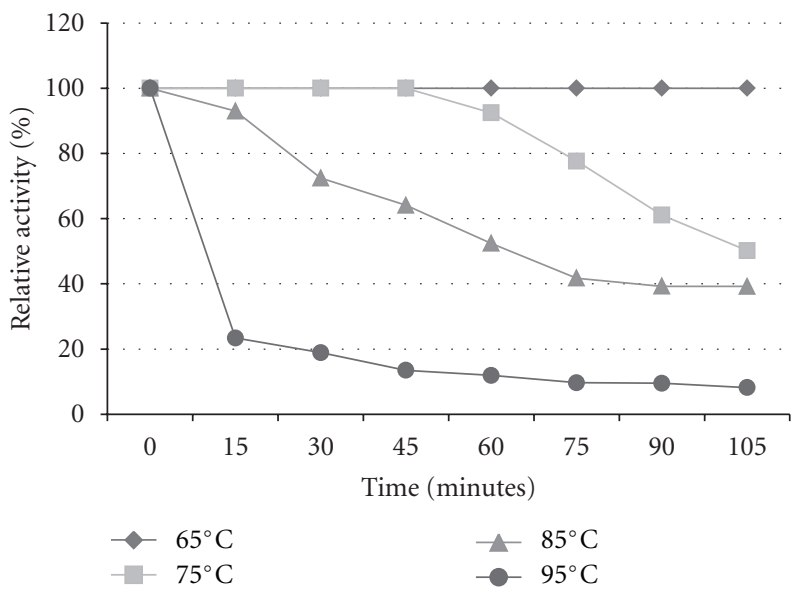

FIgURE 4: Thermostability of crude xylanase activities from strain TWXYL3. Activity was measured using standard conditions after time intervals indicated. The values are means of three replicates at each time point.

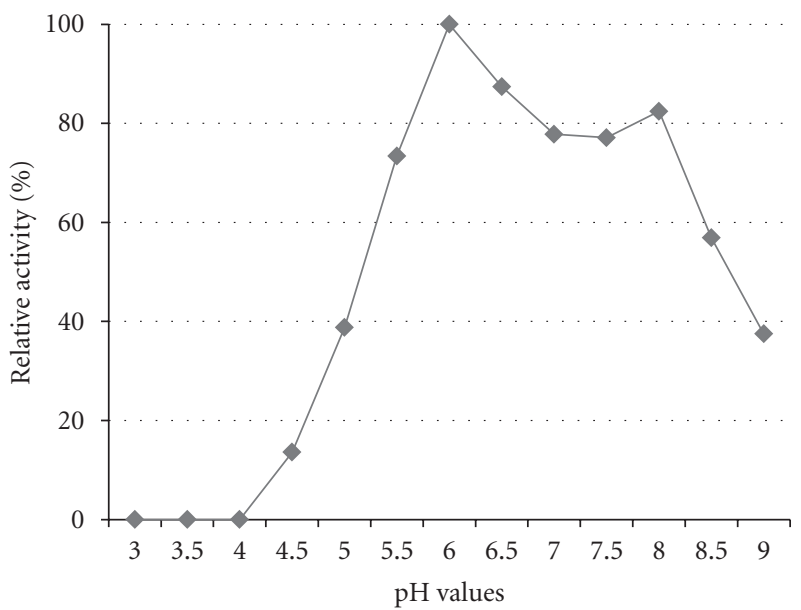

Figure 5: Effect of $\mathrm{pH}$ on crude xylanase activity from strain TWXYL3. Values are the mean of three replicates at each $\mathrm{pH}$. Assay was conducted using standard conditions; however, the $\mathrm{pH}$ was varied as indicated in the figure. 
TABle 1: General characteristics of A. flavithermus TWXYL3, A. flavithermus DSM 2641, Anoxybacillus ayderensis ABO4, and Anoxybacillus kestanbolensis $\mathrm{K} 4$ [33].

\begin{tabular}{|c|c|c|c|c|}
\hline & TWXYL3 & DSM 2641 & $\mathrm{ABO} 4$ & K4 \\
\hline Morphology & Bacilli & Bacilli & Bacilli & Bacilli \\
\hline Gram reaction & Gram positive & Gram positive & Gram positive & Gram positive \\
\hline Optimal growth temperature $\left({ }^{\circ} \mathrm{C}\right)$ & 65 & $60-65$ & $50-55$ & $50-55$ \\
\hline Temperature growth range $\left({ }^{\circ} \mathrm{C}\right)$ & $35-75$ & $30-72$ & $30-70$ & $40-70$ \\
\hline Optimal growth $\mathrm{pH}$ & 7.0 & 7.0 & $7.5-8.5$ & $7.5-8.5$ \\
\hline $\mathrm{pH}$ growth range & $6.0-10.0$ & $5.5-9.0$ & $6.0-11.0$ & $6.0-10.5$ \\
\hline Salt tolerance & $3 \% \mathrm{NaCl}$ & $2.5 \%$ & $2.5 \%$ & $4.0 \%$ \\
\hline Aerotolerance & Facultative & Facultative & Facultative & Facultative \\
\hline Motility & + & + & + & + \\
\hline Spore formation & + & + & + & + \\
\hline Biofilm formation & + & ND & ND & ND \\
\hline \multicolumn{5}{|l|}{ Hydrolysis of } \\
\hline birchwood xylan & + & ND & ND & ND \\
\hline beechwood xylan & + & ND & ND & ND \\
\hline oat Spelt xylan & + & ND & ND & $\mathrm{ND}$ \\
\hline dairy waste & + & ND & ND & ND \\
\hline Growth on & & ND & & \\
\hline cellulose & + & ND & ND & ND \\
\hline glucose & + & ND & + & + \\
\hline L-arabinose & + & + & + & + \\
\hline D-fructose & + & ND & + & + \\
\hline D-xylose & + & - & + & + \\
\hline D-galactose & + & ND & & \\
\hline D-mannose & + & + & + & + \\
\hline D-Lactose & + & - & - & - \\
\hline starch & + & ND & + & + \\
\hline sucrose & + & ND & + & + \\
\hline
\end{tabular}

characterized strains, was utilized to construct a phylogenetic tree (Figure 1).

3.2. Optimization of Xylanase Production. Cultures were grown with $1 \%$ oat spelt xylan, and the optimal incubation time was determined for xylanase production. Spectrophotometric assays show the optimal enzyme temperature and incubation time for strain TWXYL 3 to be $65^{\circ} \mathrm{C}$ for approximately 6 days (Figure 2). The specific activity of the xylanase enzymes from the crude supernatant was measured at $0.08 \mathrm{U} / \mathrm{mg}$ protein.

3.3. Characterization and Partial Purification of Extracellular Xylanases. The xylanase activities produced by strain TWXYL3 were highest between $55^{\circ} \mathrm{C}$ and $65^{\circ} \mathrm{C}$, with optimal activity at $65^{\circ} \mathrm{C}$ (Figure 3). Although the stability of these enzymes were significantly reduced at $85^{\circ} \mathrm{C}$, showing $52 \%$ activity after 60 minutes and 39\% activity after $105 \mathrm{~min}$ utes, they retained $92 \%$ activity at $75^{\circ} \mathrm{C}$ after 60 minutes (Figure 4). Xylanase enzymes were optimal at pH 6; however, they retained $38 \%$ of their activity at $\mathrm{pH} 9$ for one hour (Figure 5). The specific activity of the xylanase enzymes from the crude supernatant was measured at $0.08 \mathrm{U} / \mathrm{mg}$ protein and $2.2 \mathrm{U} / \mathrm{mg}$ protein after partial purification.

3.4. Electrophoretic and Zymographic Analysis. ND-PAGE and zymography assays from crude extracellular preparations indicate the presence of a large-molecular-weight active xylanase complex equal to or greater than $250 \mathrm{kDa}$. Despite performing the experiment at $4^{\circ} \mathrm{C}$, activity was present even during electrophoresis, as evidenced by smeared clearing zones or tracks (Figure 6). Additionally, SDS-PAGE zymography assays indicated multiple xylanase activity bands ranging from 25 to $75 \mathrm{kDa}$, with activity bands present at $25 \mathrm{kDa}, 32 \mathrm{kDa}, 37 \mathrm{kDa}, 60 \mathrm{kDa}$, and $75 \mathrm{kDa}$, also produced from strain TWXYL3 (Figure 6).

\section{Discussion}

TWXYL3 is a facultative anaerobic thermophile that secretes moderately alkalistable and thermostable xylanase enzymes into the growth medium. Phylogenetic analysis supports the relationship of strain TWXYL3 to other characterized strains of $A$. flavithermus. Table 1 shows general characteristics of $A$. flavithermus TWXYL3 as well as other similar 


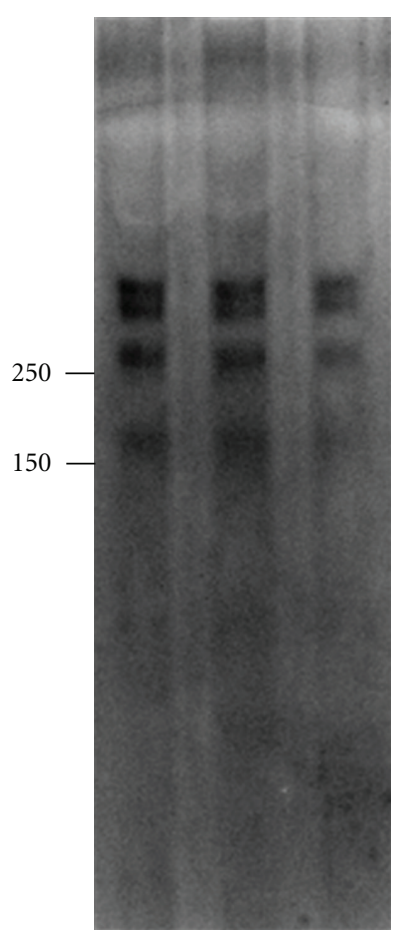

(a)

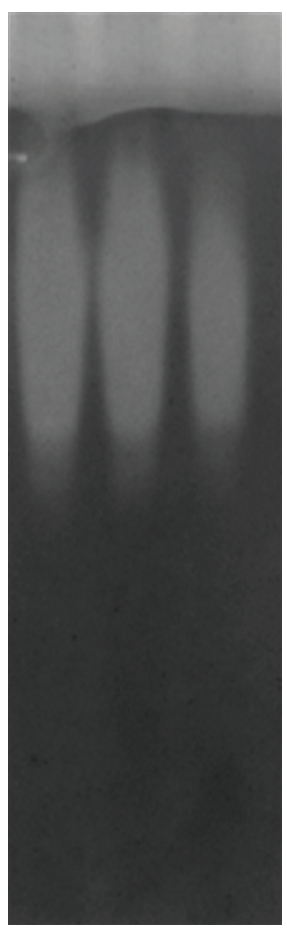

(b)

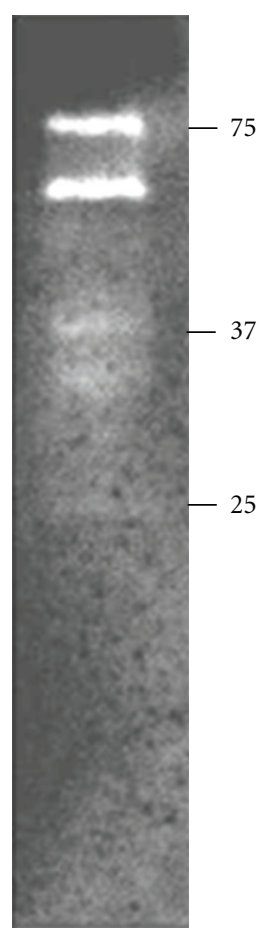

(c)

FIGURE 6: 5.0\% Tricine ND-PAGE and ND-zymogram analysis containing 0.15\% xylan, using crude xylanase preparations from strain TWXYL3, depicting the presence of high-molecular-weight proteins and high-molecular-weight active xylanases. Molecular mass markers are Precision Plus Protein Standards (Bio-Rad). (a) ND-PAGE analysis of crude enzyme preparations (50, 25, and 10 $\mu \mathrm{g}$ loading), stained with CBB. (b) Zymogram analysis of high-molecular-weight crude xylanase enzymes (50, 25, and $10 \mu \mathrm{g}$ loading). Xylanase activity is indicated by zones of clearing. (c) A 7.5\% Tricine SDS-PAGE zymogram containing $0.15 \%$ oat spelt xylan as substrate, using crude xylanase preparation $(50 \mu \mathrm{g})$ from strain TWXYL3. Xylanase activity is indicated by zones of clearing.

characterized strains. Our isolate was able to grow on a wide variety of carbohydrates, including dairy waste as the sole carbon source. This ability to degrade an abundance of lignocellulosic materials would be advantageous for industrial-scale saccharification processes.

Only one other known strain of A. flavithermus has shown xylanolytic capabilities [15], and among the genus Anoxybacillus, only the species of Anoxybacillus flavithermus has shown capable of xylan and cellulose-degrading capabilities [27]. Xylanase enzymes described here have been shown to be thermostable as well as moderately alkalistable. The thermostability of these enzymes was similar to published results of A. flavithermus BC by Kambourova et al. [15], in that these xylanases were highly stable at temperatures around $70^{\circ} \mathrm{C}$. An earlier study of A. flavithermus BC by the same group provided similar results on the alkalistability of A. flavithermus xylanase enzymes [35].

Partial purification of xylanase enzymes indicates that there was measurable and increased xylanase activity throughout purification of these enzymes. This indicates that these enzymes could be purified and employed in industrial processes. Specific activity of xylanase enzymes from strain TWXYL3 throughout enzyme purification was measured at $0.08 \mathrm{U} / \mathrm{mg}$ protein in the crude supernatant and $2.2 \mathrm{U} / \mathrm{mg}$ protein after concentration, size exclusion, and anion exchange chromatograph was employed.

These data illustrate that $A$. flavithermus TWXYL3 shows interesting xylanolytic capabilities in that it secretes a large pentameric enzyme complex into the growth media, which has never been described by this species. This complex, or xylanosome, is composed of at least 5 active protein subunits ranging from $25 \mathrm{kDa}$ to $75 \mathrm{kDa}$, suggesting a pentameric protein complex approximately $250 \mathrm{kDa}$ in size (Figure 6). This data is unique from the xylanase activity described for Strain BC [15], in that they illustrated only two active xylanase enzymes at $92 \mathrm{kDa}$ and $80 \mathrm{kDa}$. The presence of a large-molecular-weight active complex from strain TWXYL3 is further supported by the elution profile from the S-200 high-resolution size exclusion column (data not shown). The active fractions are eluted in the area of a $200 \mathrm{kDa}$ or larger protein when compared to standards of greater than $200 \mathrm{kDa}$. Thermophiles typically produce family 10 (large molecular mass) and family 11 (small molecular mass) xylanases [36], and the profile of xylanase proteins detected in TWXYL3 is consistent with this pattern.

The ability of A. flavithermus TWXYL3 to produce a large xylanolytic complex may serve to provide higher adaptability to degrade an assortment of complex polysaccharides or perhaps to fully degrade xylan into its monosaccharide 
components. Thermostable xylanases from microorganisms provide great benefit in that they can retain their activities at high temperatures, while preventing potential contamination due to these high temperatures [37]. Additionally, thermostable enzymes simplify cooling problems from pretreated biomass [37, 38]. Xylanases described here would be ideal for certain industrial applications $[2,27]$, particularly biobleaching of pulp $[6,18]$ and saccharification processes [6] due to their adaptive capacity to withstand hostile conditions. This microorganism and its extracellular xylanases show potential in large scale-up reactors, for the conversion of agricultural waste products rich in lignocellulose, which are cheap and abundant, for use in downstream fermentation processes into high-value biofuels.

\section{Conflict of Interests}

The authors have no direct financial relationship with any commercial identity mentioned within this paper. Thus, no conflict of interests exists as this research was not conducted to advertise or provide financial gain for any of the abovementioned commercial identities.

\section{Acknowledgments}

The authors are grateful for support from the Center for Advanced Energy Studies (CAES). They thank Michael Swenson, Don McGuire, Tamara Salazar, and Binita Shakya for laboratory assistance and Erin O' Leary-Jepsen and Christine Ryan from the Molecular Research Core Facility at Idaho State University for DNA sequence determination.

\section{References}

[1] Z. X. Lu, A. Laroche, and H. C. Huang, "Segregation patterns for integration and expression of Coniothyrium minitans xylanase gene in Arabidopsis thaliana transformants," Botanical Bulletin of Academia Sinica, vol. 45, no. 1, pp. 23-31, 2004.

[2] G. Mamo, M. Thunnissen, R. Hatti-Kaul, and B. Mattiasson, "An alkaline active xylanase: insights into mechanisms of high pH catalytic adaptation," Biochimie, vol. 91, no. 9, pp. 11871196, 2009.

[3] P. Dwivedi, V. Vivekanand, N. Pareek, A. Sharma, and R. P. Singh, "Bleach enhancement of mixed wood pulp by xylanase-laccase concoction derived through co-culture strategy," Applied Biochemistry and Biotechnology, vol. 160, no. 1, pp. 255-268, 2010.

[4] T. S. Magnuson, Biochemical and genetic studies on the lignocellulose degradation system of streptomyces viridosporus T7A [dissertation thesis], University of Idaho, Moscow, Russia, 1996.

[5] C. Valls and M. B. Roncero, "Using both xylanase and laccase enzymes for pulp bleaching," Bioresource Technology, vol. 100, no. 6, pp. 2032-2039, 2009.

[6] S. Nagar, V. K. Gupta, D. Kumar, L. Kumar, and R. C. Kuhad, "Production and optimization of cellulase-free, alkali-stable xylanase by Bacillus pumilus SV-85S in submerged fermentation," Journal of Industrial Microbiology and Biotechnology, vol. 37, no. 1, pp. 71-83, 2010.

[7] M. Q. Wang, C. Saricks, and M. Wu, "Fuel-Cycle Fossil Energy Use and Greenhouse Gas Emissions of Fuel Ethanol
Produced from U.S. Midwest Corn," Prepared for Illinois Department of Commerce and Community Affairs, Center for Transportation Research, Argonne National Laboratory, Argonne, Ill, USA, 1997.

[8] S. Ahmed, S. Riaz, and A. Jamil, "Molecular cloning of fungal xylanases: an overview," Applied Microbiology and Biotechnology, vol. 84, no. 1, pp. 19-35, 2009.

[9] I. D. Choi, H. Y. Kim, and Y. J. Choi, "Gene cloning and characterization of $\alpha$-glucuronidase of Bacillus stearothermophilus No. 236," Bioscience, Biotechnology and Biochemistry, vol. 64, no. 12, pp. 2530-2537, 2000.

[10] G. M. Zhang, J. Huang, G. R. Huang, L. X. Ma, and X. E. Zhang, "Molecular cloning and heterologous expression of a new xylanase gene from Plectosphaerella cucumerina," Applied Microbiology and Biotechnology, vol. 74, no. 2, pp. 339-346, 2007.

[11] H. Wei, Q. Xu, L. E. Taylor, J. O. Baker, M. P. Tucker, and S. Y. Ding, "Natural paradigms of plant cell wall degradation," Current Opinion in Biotechnology, vol. 20, no. 3, pp. 330-338, 2009.

[12] S. Marques, L. Alves, S. Ribeiro, F. M. Gírio, and M. T. AmaralCollaço, "Characterization of a thermotolerant and alkalotolerant xylanase from a Bacillus sp.", Applied Biochemistry and Biotechnology A, vol. 73, no. 2-3, pp. 159-172, 1998.

[13] C. Mawadza, R. Hatti-Kaul, R. Zvauya, and B. Mattiasson, "Purification and characterization of cellulases produced by two Bacillus strains," Journal of Biotechnology, vol. 83, no. 3, pp. 177-187, 2000.

[14] A. S. S. Ibrahim and A. I. El-diwany, "Isolation and identification of new cellulases producing thermophilic bacteria from an Egyptian hot spring and some properties of the crude enzyme," Australian Journal of Basic and Applied Sciences, vol. 1, pp. 473-478, 2007.

[15] M. Kambourova, R. Mandeva, I. Fiume, L. Maurelli, M. Rossi, and A. Morana, "Hydrolysis of xylan at high temperature by co-action of the xylanase from Anoxybacillus flavithermus $\mathrm{BC}$ and the $\beta$-xylosidase/ $\alpha$-arabinosidase from Sulfolobus solfataricus $\mathrm{O} \alpha$," Journal of Applied Microbiology, vol. 102, no. 6, pp. 1586-1593, 2007.

[16] A. Pakpitcharoen, K. Potivejkul, P. Kanjanavas, S. Areekit, and K. Chansiri, "Biodiversity of thermotolerant Bacillus $s p$. producing biosurfactants, biocatalysts, and antimicrobial agents," ScienceAsia, vol. 34, no. 4, pp. 424-431, 2008.

[17] P. Biely, D. Mislovičová, and R. Toman, "Soluble chromogenic substrates for the assay of endo-1,4- $\beta$-xylanases and endo-1,4$\beta$-glucanases," Analytical Biochemistry, vol. 144, no. 1, pp. 142146, 1985.

[18] M. C. T. Duarte, A. C. A. Pellegrino, E. P. Portugal, A. N. Ponezi, and T. T. Franco, "Characterization of alkaline xylanases from Bacillus pumilus," Brazilian Journal of Microbiology, vol. 31, no. 2, pp. 90-94, 2000.

[19] B. H. Howard, G. Jones, and M. R. Purdom, "The pentosanases of some rumen bacteria," The Biochemical Journal, vol. 74, pp. 173-180, 1960.

[20] C. C. Lee, R. E. Kibblewhite-Accinelli, M. R. Smith, K. Wagschal, W. J. Orts, and D. W. S. Wong, "Cloning of Bacillus licheniformis xylanase gene and characterization of recombinant enzyme," Current Microbiology, vol. 57, no. 4, pp. 301-305, 2008.

[21] A. Sharma, S. Adhikari, and T. Satyanarayana, "Alkalithermostable and cellulase-free xylanase production by an extreme thermophile Geobacillus thermoleovorans," World Journal of Microbiology and Biotechnology, vol. 23, no. 4, pp. 483-490, 2007. 
[22] P. K. Smith, R. I. Krohn, and G. T. Hermanson, "Measurement of protein using bicinchoninic acid," Analytical Biochemistry, vol. 150, no. 1, pp. 76-85, 1985.

[23] L. Weinstein and P. Albersheim, "Structure of plant-cell walls .IX. Purification and partial characterization of a walldegrading endoarabanase and an arabinosidase from Bacillus subtilis," Plant Physiology, vol. 63, pp. 425-432, 1979.

[24] R. P. Anex, L. R. Lynd, M. S. Laser, A. H. Heggenstaller, and M. Liebman, "Potential for enhanced nutrient cycling through coupling of agricultural and bioenergy systems," Crop Science, vol. 47, no. 4, pp. 1327-1335, 2007.

[25] S. K. Lee, H. Chou, T. S. Ham, T. S. Lee, and J. D. Keasling, "Metabolic engineering of microorganisms for biofuels production: from bugs to synthetic biology to fuels," Current Opinion in Biotechnology, vol. 19, no. 6, pp. 556-563, 2008.

[26] M. B. Sticklen, "Expediting the biofuels agenda via genetic manipulations of cellulosic bioenergy crops," Biofuels, Bioproducts and Biorefining, vol. 3, no. 4, pp. 448-455, 2009.

[27] Y. Liang, Z. Feng, J. Yesuf, and J. W. Blackburn, “Optimization of growth medium and enzyme assay conditions for crude cellulases produced by a novel thermophilic and cellulolytic bacterium, Anoxybacillus sp. 527," Applied Biochemistry and Biotechnology, vol. 160, no. 6, pp. 1841-1852, 2010.

[28] D. Dodd and I. K. O. Cann, "Enzymatic deconstruction of xylan for biofuel production," GCB Bioenergy, vol. 1, pp. 2-17, 2009.

[29] P. C. Badger, Ethanol from Cellulose: A General Review Reprinted from: Trends in New Crops and New Uses, Edited by J. Janick and A. Whipkey, ASHS Press, Alexandria, VA, USA, 2002.

[30] D. J. Lane, 16S/23S rRna Sequencing. Nucleic Acid Techniques. Bacterial Systematics, Edited by Stackebrandt E., Goodfellow M., John Wiley and Sons, New York, NY, USA, 1991.

[31] I. Kimura, H. Sasahara, and S. Tajima, "Purification and characterization of two xylanases and an arabinofuranosidase from Aspergillus sojae," Journal of Fermentation and Bioengineering, vol. 80, no. 4, pp. 334-339, 1995.

[32] H. Schagger and G. Von Jagow, "Tricine-sodium dodecyl sulfate-polyacrylamide gel electrophoresis for the separation of proteins in the range from 1 to $100 \mathrm{kDa}$," Analytical Biochemistry, vol. 166, no. 2, pp. 368-379, 1987.

[33] S. Dulger, Z. Demirbag, and A. O. Belduz, "Anoxybacillus ayderensis sp. nov. and Anoxybacillus kestanbolensis sp. nov," International Journal of Systematic and Evolutionary Microbiology, vol. 54, no. 5, pp. 1499-1503, 2004.

[34] H. Matsui, K. Ogata, K. Tajima et al., "Phenotypic characterization of polysaccharidases produced by four Prevotella type strains," Current Microbiology, vol. 41, no. 1, pp. 45-49, 2000.

[35] P. L. Dimitrov, M. S. Kambourova, R. D. Mandeva, and E. I. Emanuilova, "Isolation and characterization of xylandegrading alkali-tolerant thermophiles," FEMS Microbiology Letters, vol. 157, no. 1, pp. 27-30, 1997.

[36] T. Collins, C. Gerday, and G. Feller, "Xylanases, xylanase families and extremophilic xylanases," FEMS Microbiology Reviews, vol. 29, no. 1, pp. 3-23, 2005.

[37] Y. Liang, J. Yesuf, and Z. Feng, "Toward plant cell wall degradation under thermophilic condition: a unique microbial community developed originally from swine waste," Applied Biochemistry and Biotechnology, vol. 161, no. 1-8, pp. 147-156, 2010.

[38] A. L. Demain, M. Newcomb, and J. H. D. Wu, "Cellulase, clostridia, and ethanol," Microbiology and Molecular Biology Reviews, vol. 69, no. 1, pp. 124-154, 2005. 

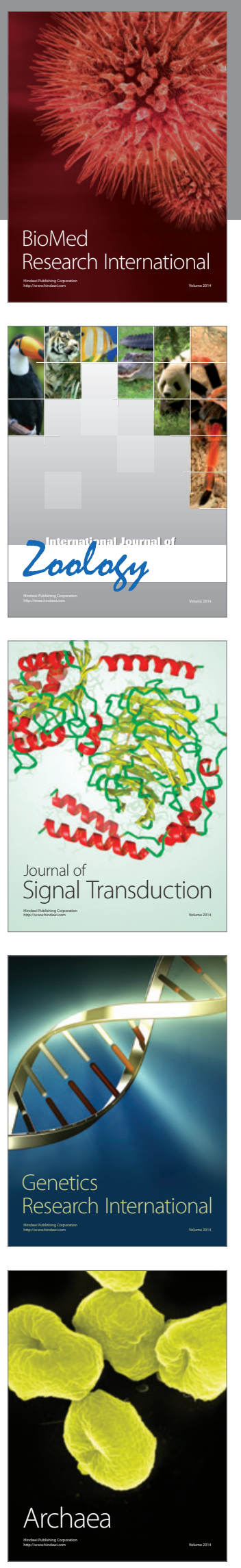
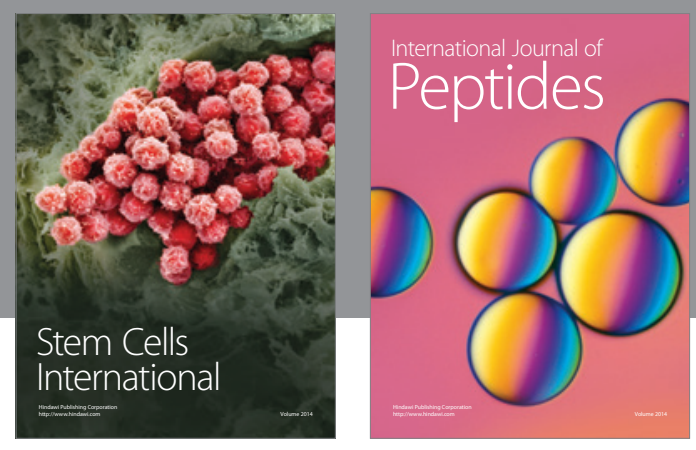

Submit your manuscripts at

http://www.hindawi.com
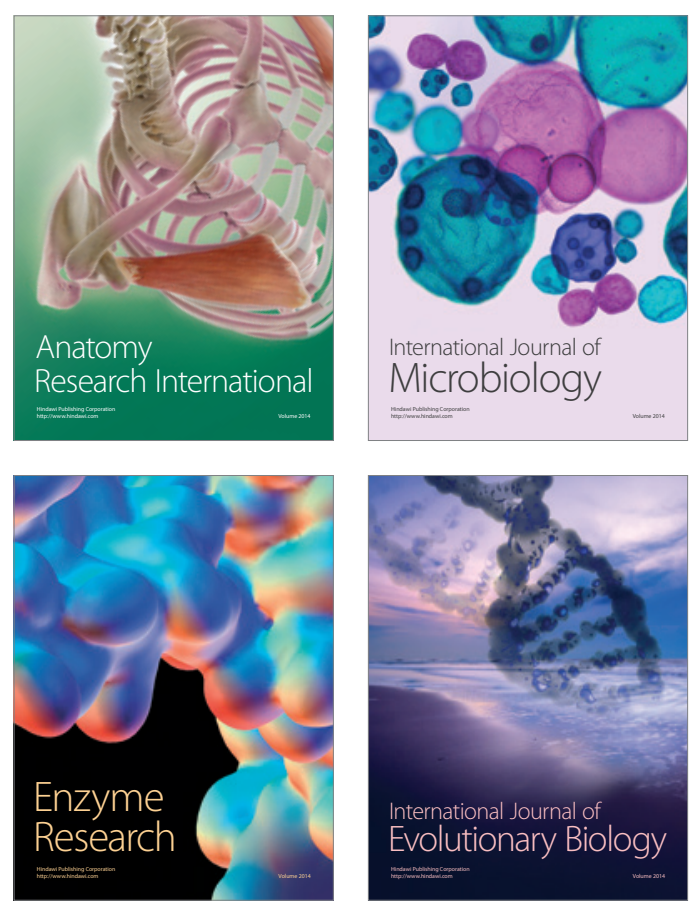
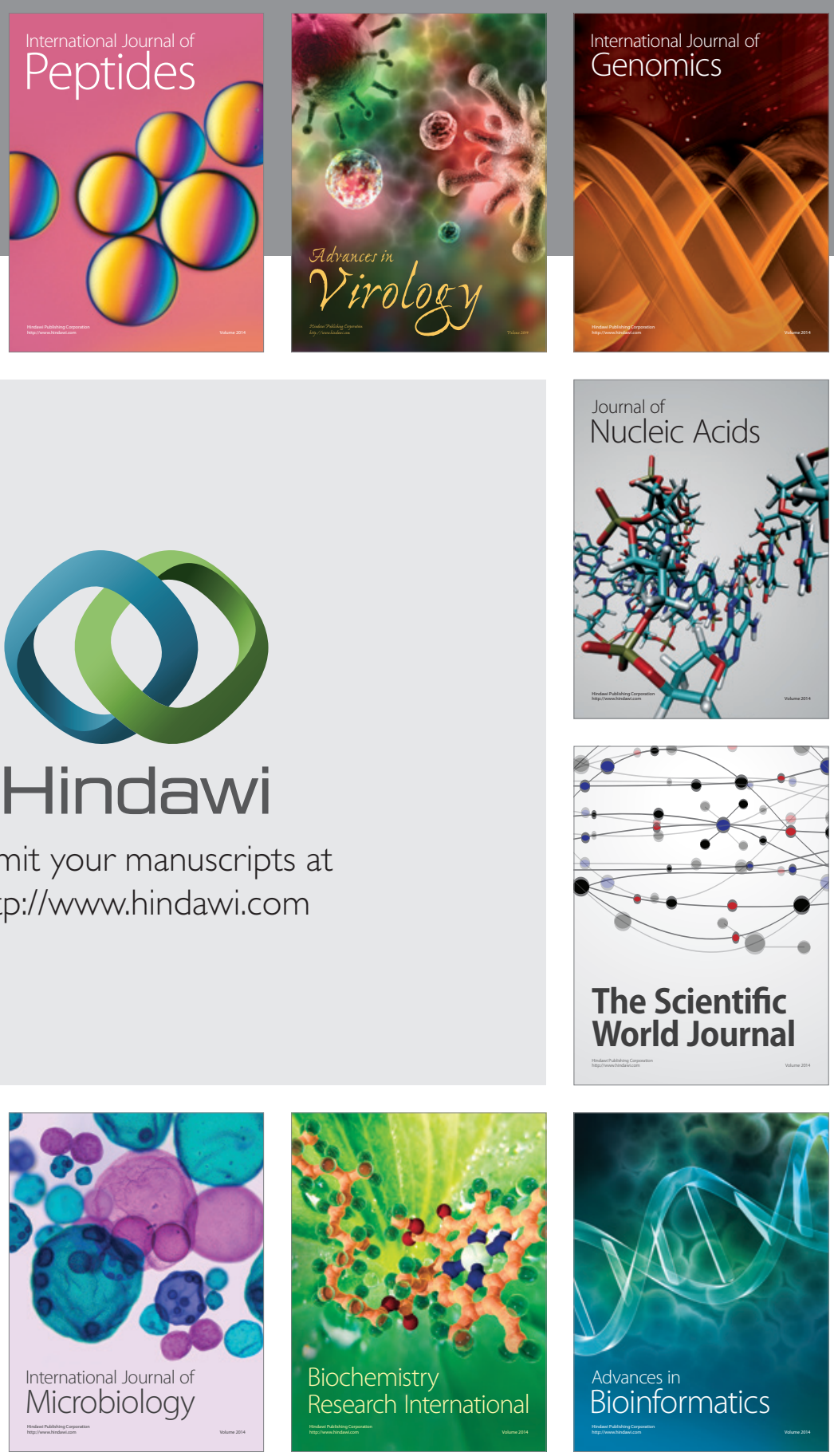

The Scientific World Journal
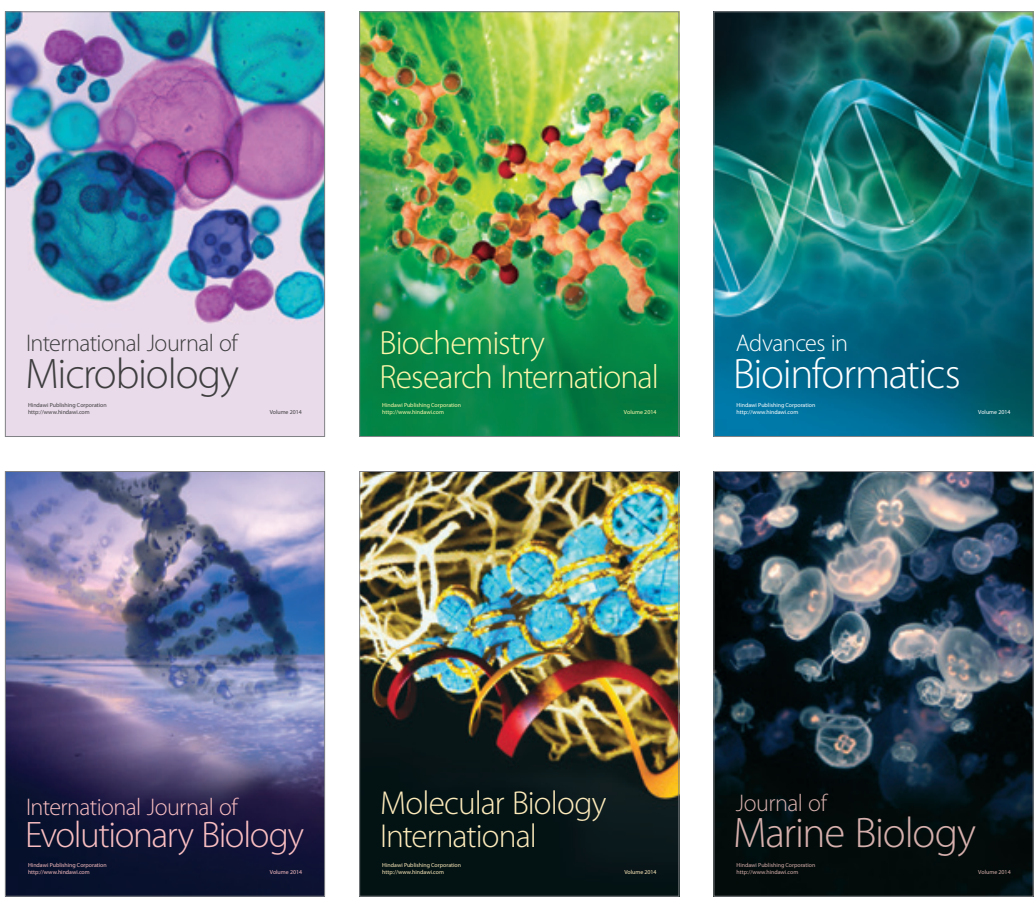